\title{
Optimalisasi Pengelolaan Dana Ziswaf dalam Meningkatkan Kesejahteraan Ekonomi Anggota Koperasi Syari'ah Benteng Mikro Indonesia Cabang Cikupa, Tanggerang
}

\author{
Didi Suardi \\ Sekolah Tinggi Ekonomi Syariah Islamic Village Tangerang, Indonesia \\ didi@stes.isvill.ac.id \\ Jafar Abdul Hafidz \\ Sekolah Tinggi Ekonomi Syariah Islamic Village Tangerang, Indonesia \\ jafarhafidz97@gmail.com
}

\begin{abstract}
Abstrack:
This study aims to understand the ZISWAF fund management strategy carried out by the Benteng Mikro Indonesia Sharia Cooperative (BMI) Cikupa Tangerang Branch in improving welfare for members and non-members. Research at the location was motivated by the success of the cooperative in making efforts to optimize it, even that success was not only felt by cooperative members, nonmembers also felt. This success has inspired researchers to go directly to the field, see and ask questions about the ZIZWAF fund management strategy in depth. This is because researchers have observed that various zakat fund management has not been maximized, some are stagnant, some are declining and not developing. So it is necessary to look for zakat management formulations that have been proven to be optimal. For this reason, this study uses qualitative analysis methods with data collection techniques through observation, in-depth interviews, and documentation. The random sampling technique is random sampling. The determination of the sampling technique or informant depends on the topic and the objectives of the research itself. The results show that in terms of the management of Islamic cooperatives, BMI has planned programs to improve the economic welfare of members and non-members of the branch of the BMI Islamic cooperative. Cikupa. However, the impact is still not felt by members and non-members because it is not in accordance with their needs. However, the BMI sharia cooperative has a Ready-to-Live Home Grant (HRSH) program, this program is very helpful for members and non-members who do not have a house or have a house that is not suitable for habitation.
\end{abstract}

Keywords: Management Optimization, ZISWAF Fund, Economic Welfare 


\section{Latar Belakang}

Jumlah penduduk miskin di Indonesia pada Maret 2020 mencapai 26,42 juta orang. Dibandingkan September 2019, jumlah penduduk miskin meningkat 1,63 juta orang. Sementara jika dibandingkan dengan Maret 2019, jumlah penduduk miskin meningkat sebanyak 1,28 juta orang. Persentase penduduk miskin pada Maret 2020 tercatat sebesar 9,78 persen, meningkat 0,56 persen poin terhadap September 2019 dan meningkat 0,37 persen poin terhadap Maret 2019. Berdasarkan daerah tempat tinggal, pada periode September 2019-Maret 2020, jumlah penduduk miskin di daerah perkotaan naik sebesar 1,3 juta orang, sedangkan di daerah perdesaan naik sebesar 333,9 ribu orang. Persentase kemiskinan di perkotaan naik dari 6,56 persen menjadi 7,38 persen. Sementara itu, di perdesaan naik dari 12,60 persen menjadi 12,82 persen. $^{1}$

Lingkaran kemiskinan yang terbentuk dalam masyarakat lebih banyak kemiskinan struktural sehingga upaya mengatasinya harus dilakukan melalui upaya yang bersifat prinsip dan sistematis. Menurut fakta, bahwa jumlah umat Islam di Indonesia yang mampu menunaikan zakat terus bertambah, jika potensi ekonomi umat itu dikelola dan dikembangkan secara produktif, tentu akan diperoleh hasil yang optimal. Agar dapat menjadi sumber dana yang dapat dimanfaatkan bagi kesejahteraan terutama untuk mengentaskan masyarakat dari kemiskinan dan menghilangkan kesenjangan sosial, perlu adanya pengelolaan zakat secara profesional dan bertanggung jawab yang dilakukan oleh masyarakat bersama pemerintah. ${ }^{2}$

Zakat yang merupakan bagian dari harta yang wajib diberikan oleh setiap muslim yang telah memenuhi syarat yang diberikan kepada orangorang tertentu dengan syarat syarat tertentu pula. ${ }^{3}$ Dengan nilai-nilai yang terkandung dalam ajaran Zakat dalam Islam dapat dipahami bahwa zakat dapat pula sebagai cambuk yang ampuh, yang mebuat zakat tidak hanya menciptakan pertumbuhan material dan spiritual bagi orang-orang miskin, tetapi juga dapat mengembangkan jiwa orang-orang kaya dermawan. Selain itu, zakat juga merupakan salah satu dari lima nilai instrumental yang strategis dan sangat berpengaruh pada tingkah laku ekonomi manusia dan masyarakat serta pembangunan ekonomi

1 Badan Pusat Statistik Indonesia, "Profil Kemiskinan di Indonesia" Maret 2020 No. 56/07/Th. XXIII, 15 Juli 2020, 2-3

${ }^{2}$ A Rio Makkulau Wahyu dan Wirani Aisiyah Anwar, "Sistem Pengelolaan Zakat Pada Baznas," Al-Azhar Journal Of Islamic Economics, 2, 1 (2020), 14.

${ }^{33}$ Rahmawati Muin, Manajemen Zakat, (Makassar: Alauddin University Press, 2011), 3. 
umumnya. ${ }^{4}$ Zakat, Infaq dan Shadaqah (ZIS) merupakan ibadah yang tidak hanya berhubungan dengan nilai ketuhanan saja, namun berkaitan juga dengan hubungan kemanusiaan yang bernilai sosial (maliyah ijtima"iyyah).

ZIS memiliki manfaat yang sangat penting dan strategis dilihat dari sudut pandang ajaran Islam maupun dari aspek pembangunan kesejahteraan umat. Hal ini telah dibuktikan dalam sejarah perkembangan Islam yang diawali sejak masa kepemimpinan Rasululah SAW. Zakat telah menjadi sumber pendapatan keuangan negara yang memiliki peranan sangat penting antara lain sebagai sarana pengembangan agama Islam, pengembangan dunia pendidikan dan ilmu pengetahuan, pengembangan infrastruktur dan penyediaan layanan bantuan untuk kepentingan kesejahteraan sosial masyarakat yang kurang mampu seperti fakir miskin serta bantuan lainnya. Tujuan zakat tidak sekedar menyantuni orang miskin secara konsumtif, tetapi mempunyai tujuan yang lebih permanen yaitu mengentaskan kemiskinan. ${ }^{5}$

Upaya untuk menggali potensi dan optimalisasi peran zakat di Indonesia belum sepenuhnya tergarap dengan maksimal karena peran zakat belum terlaksana secara efektif dan efisien. Banyak faktor yang menyebabkan manfaat dari zakat ini belum terasa maksimal, diantaranya adalah lemahnya motivasi keagamaan dan kesadaran keislaman pada mayoritas masyarakat sehingga rendahnya kesadaran masyarakat dalam menunaikan kewajiban membayar zakat, kurangnya pengawasan dari lembaga-lembaga pengelola zakat dalam pendistribusian zakat sehingga mungkin pihak-pihak yang semestinya mendapatkan zakat tidak mendapatkan haknya, zakat itu diberikan kepada delapan golongan jangan hanya diberikan kepada golongan fakir dan miskin saja, zakat yang diberikan kepada para mustahik sebagian besar digunakan untuk konsumsi sesaat sehingga tidak terjadi kegiatan ekonomi yang bisa mengembangkan harta si mustahik, dan seharusnya zakat yang diberikan oleh muzakki kepada mustahik jangan hanya dalam bentuk uang tetapi juga dalam bentuk modal usaha dan beasiswa pendidikan. ${ }^{6}$

Penerbitan undang-undang No 23 Tahun 2011 Tentang Pengelolaan dana Zakat yang menunjukan keseriusan pemerintah untuk terus mengembangkan instrumen zakat. Bahkan pemerintah bersama dengan

4 Ahmad M. Saefuddin, Ekonomi dan Masyarakat dalam Prespektif Islam (Jakarta: CV. Rajawali, 1987), 71.

5 Abdurrachman Qadir, Zakat Dalam Dimensi Mahdah dan Sosial, (Jakarta: RajaGrafindo Persada, 2001), 83-84.

${ }^{6}$ Kasyful Mahalli, Potensi Dan Peranan Zakat.," Jurnal Ekonomi dan Keuangan 1Departemen pembangunan USU (2013): 71. 
swasta telah mengelola dana zakat tersebut secara terlembaga dalam lembaga Badan Amil Zakat. Salah satu faktor untuk menjadikan pengelolaan zakat lebih optimal adalah potensi zakat yang belum tergali secara maksimal. ${ }^{7}$

Islam menginginkan umatnya untuk memiliki paradigma bahwa zakat sesungguhnya bukan sekadar charity atau kedermawanan sosial. Ia merupakan bentuk investasi yang bersifat ukhrawi dan duniawi. Bertambahnya harta yang dikeluarkan zakatnya di sisi Allah swt. menunjukkan bahwa ia pada hakikatnya merupakan investasi yang bersifat ukhrawi. Sedangkan yang bersifat duniawi adalah zakat dapat mendorong pembukaan lapangan pekerjaan baru, sehingga akan meningkatkan pendapatan dan daya beli kaum du'afa. Peningkatan tersebut pada akhirnya akan mendorong tumbuhnya perekonomian masyarakat.

Melalui paradigma demikian, diharapkan akan muncul kesadaran dan orientasi masyarakat yang lebih mencintai untuk memberi dari pada menerima. Dengan semangat ini pula, masyarakat akan terpacu untuk meningkatkan produktivitasnya dan mengoptimalkan segala potensi yang dimilikinya, sebab bagaimana mungkin ia akan mampu memberi dan berinvestasi jika ia tidak produktif menghasilkan sesuatu. Tipe masyarakat yang produktif inilah yang sesungguhnya menjadi dasar pembangunan peradaban Islam di masa depan ${ }^{8}$ Mencermati dari sisi sosial ekonomi, bahwa zakat memang terlihat jelas mempunyai efek penting yang menyentuh kehidupan sosial ekonomi di masyarakat. Mereka yang sangat membutuhkan bantuan materi melalui harta zakat seperti fakir miski dapat teratasi atau setidaknya meringankan beban hidupnya. Sehingga zakat mempunyai peran dalam menjembatani harta antara yang kaya dengan yang miskin. ${ }^{9}$

Indonesia Negara dengan mayoritas muslim terbanyak harus bisa memaksimalkan dana ZISWAF. (Zakat Infaq Shodaqoh dan Wakaf) yang merupakan sesuatu hal yang penting dimana pemanfaatan nya telah di jelaskan dalam al-Qur'an dan Hadist. Instrumen ZISWAF selain menjaga Hubungan antara sesama manusia dan Allah SWT, juga akan menjaga kasih sayang sesama manusia saling bersaudara, juga menolong sesama

7 Nurwati Nurwati dan Heni Hendrawati, "Zakat dan Upaya Mengentaskan Kemiskinan," Cakrawala: Jurnal Studi Islam 14, 1 (2019), 40-41,

8 Hasanuri Hasanuri, "Pengembangan zakat untuk perekonomian masyarakat," AlKharaj: Journal of Islamic Economic and Business 1, 2 (2020): 112.

${ }^{9}$ Ainol Yaqin, "Optimalisasi Zakat Produktif dalam Pengentasan Problem Kemiskinan," Iqtishadia: Jurnal Ekonomi \& Perbankan Syariah 2, 2 (2015): 225, 
antara yang kuat dengan yang lemah atau yang kaya dengan yang miskin dalam kehidupan. ${ }^{10}$

\section{Metode Penelitian}

Teknik pengumpulan data yang digunakan yaitu dengan teknik wawancara kepada 8 informan yang terdiri dari informan inti, informan pendukung dan ahli. Informan inti terdiri dari 1 orang Manajer Kopsyah BMI Cabang Cikupa, 1 orang Staf Lapang Kopsyah BMI Cabang Cikupa, 1 orang Manajer ZISWAF Kopsyah BMI Pusat, 4 orang Anggota dan Non Anggota penerima dana ZISWAF Kopsyah BMI Cabang Cikupa dan 1 orang pakar/ahli dari BAZNAS Kota Tangerang. Uji Keabsahan Data yang digunakan dalam penelitian ini yaitu terdiri dari: a. Uji Credibilitas data atau kepercayaan terhadap data hasil penelitian kualitatif yaitu dilakukan dengan perpanjangan pengamatan, peningkatan ketekunan dalam penelitian, triangulasi, analisi kasus negatif, b. Uji transferbility, peneliti diwajibkan untuk membuat laporan hasil penelitian dengan menguraikan secara rinci, jelas, sistematis dan dapat dipercaya terhadap hasil penelitiannya, supaya pembaca dapat memahami hasil dari penelitian tersebut, dan c. Uji depenability disebut juga realibilitas yaitu dilakukan dengan cara mengaudit seluruh proses penelitian. Suatu penelitian dapat dikatakan reliabel apabila proses penelitian dapat diulangi kembali oleh orang lain.

\section{Hasil Penelitian}

Setelah dilakukan penelitian di Koperasi Syariah Banteng Mikro Indonesia cabang Cikupa Tanggerang Banten, dimana dilakukan pemberdayaan anggota dan non anggota koperasi dari yang lemah secaraa ekonomi menjadi berdaya serta termasuk pada kategori muzakki, dikatakan optimal. Dalihnya, para anggota koperasi tersebut sejak bergabung menalami banyak peningkatan usahah dan pendapatan keluarga. Sehingga lembaga koperasi ini tak ubahnya seperti lembaga zakat yang mengelola melalui penghimpunan, pengorganisasian dan pendistribusian dana zakat.

Optimalisasi yang dilakukan Koperasi Syariah Banteng Mikro Indonesia cabang Cikupa Tanggerang Banten terhadap anggota dan non anggota memiliki orientasi ganda, yaitu satu sisi mengembangkan usaha yang dimiliki oleh anggota dan di sisi lain memasukan mereka ke dalam bagian usaha koperasi, sehingga dapat bekerja dan menghidupi keluarga

10 Khurul Aimmatul Ummah dkk, "Pola Impementasi Alokasi ZISWAF dalam Penyediaan Akses Pendidikan bagi Kaum Dhuafa" JEBI (Jurnal Ekonomi dan Bisnis Islam) 3, 2(2018) 248. 
yang kurang mampu. Orientasi ini berjalan efektif dan telah banyak anggota yang terbantu. Koperasi bertindak sebagai fasilitator, investor sekaligus pengawas. Berikut tahapan manajemen koperasi yang berhasil diteliti.

\section{Proses Pengelolaan}

Berdasarkan hasil wawancara dengan Bapak Casmita selaku Manajer ZISWAF Koperasi Syariah BMI Pusat beliau yang mengatakan bahwa Proses pengeolaan dana ZISWAF di Koperasi Syariah BMI Cabang Cikupa ini dilakukan dengan cara mengaruskan anggotanya untuk membayar dana ZISWAF satu juta satu orang, pembayarannya tidak harus cash, dapat dilakukan dengan cara cicilan. Cara mengumpulkan dana yaitu bagian staff lapangan membawa celengan dan bertemu langsung dengan Masyarakat. ${ }^{11}$ Bapak Subur selaku Informan Ahli menyatakan bahwa pengelolaan menurut UUD No 23 Tahun 2011 harus meliputi beberapa kegiatan, seperti perencanaan, pelaksanan dan pelaporan yang dibuat setiap tahunnya.

\section{Prose Penyaluran}

Terkait penyaluran dana ZISWAF di koperasi Syariah BMI Cabang Cikupa Tangerang, peneliti melakukan wawancara dengan Bapak Tony selaku Staff Lapang Koperasi Syariah BMI Cabang Cikupa Tangerang, beliau mengatakan bahwa penyaluran dana ZISWAF salah satunya dialokasikan untuk Sanitasi Masjid dan Pesantren, Rumah Hibah Siap Huni (HRSH) santunan Yatim dan Dhuafa dan lain sebagainya. ${ }^{12}$ Penyaluran ini dilakukan sesuai dengan wilayah layanan koperasi, yakni wilayah cikupa dan sekitarnya, yang mana dalam prosesnya salah satu pihak Koperasi akan mendatangi rumah calon penerima didampingi oleh pihak pusat untuk dilakukan dokumentasi dan pelaporan. " 13

Kini di tahun 2019, Koperasi syariah BMI Cabang Cikupa sudah memiliki 27 anak asuh untuk uang bulanan dan biaya sekolah mulai dari SD hingga Perguruan Tinggi. Selajutnya ada program Sanitasi Masjid dan Pesantren yang hingga saat ini jumlahnya sudah mencapai 115 Masjid, disamping itu pula penyaluran untuk kaum Dhuafa yang membutuhkan Sanitasi Kamar mandi, dan program Ambulan gratis untuk masyarakat

${ }^{11}$ Hasil Wawancara dengan Bapak Casmita Selaku Manajer ZISWAF Koperasi Syariah BMI Pusat pada 27 April 2020 .

${ }^{12}$ Hasil Wawancara dengan Bapak Tony Sehabudin selaku Staff Lapang Koperasi Syariah BMI Cabang Cikupa Tangerang, jumat 24 april 2020

${ }^{13}$ Hasil Wawamcara dengan Bapak Mulyadi S.ip, selaku Manajer Koperasi Syariah BMI Cabang Cikupa Tangerang , Selasa 21 April 2020 
yang tidak mampu. ${ }^{14}$ Namun Bapak Subur sebagai pakar ZISWAF mengatakan bahwa masyarakat yang mendapat bantuan jangan sampai merasa ketergantungan kepada lembaga amil, oleh sebab itu untuk memutus mata rantai kemiskinan para mustahiq lembaga pengelola zakat harus membuat program-program yang berkaitan dengan pemberdayaan dan pengentasan kemiskinan. ${ }^{15}$

\section{Dampak Perubahan}

Terkait dampak perubahan Anggota dan Non Anggota koperasi syariah BMI Cabang Cikupa terhadap dana ZISWAF yang diberikan apakah sudah mengalami perubahan, beliau mengatakan bahwa belum terjadi perubahan yang signifikan. ${ }^{16}$ namun hal ini berbeda dengan pendapat Ibu Anamisna dan Ibu Nenih yang mengatakan bahwa program-program yang diberikan oleh Koperasi Syariah BMI Cabang Cikupa Tangerang sangat berdampak sigifikan melalui program renovasi rumah.

\section{Kesimpulan}

Proses pengelolaan dana ZISWAF pada Koperasi Syariah Benteng Mikro Indonesia sudah dilakukan dengan baik. Namun dalam pendistribusiannya belum berdampak signifikan untuk peningkatan kesejahteraan baik bagi anggota maupun non anggota koperasi, karena Sebagian program-progam yang ada belum sesuai dengan yang dibutuhkan para anggota dan non anggota Koperasi Syariah Benteng Mikro Indonesia Cabang Cikupa. Namun untuk program Rumah Hibah Siap Huni (HRSH) yang cukup membantu bagi mereka yang memiliki rumah tidak layak.

\footnotetext{
${ }^{14}$ Hasil Wawancara dengan Bapak Casmita , Selaku Manajer ZISWAF Koperasi Syariah BMI Pusat, 27 April 2020

15 Hasil wawancara dengan Bapak Subur selaku Wakil Ketua IV BAZNAS Kota Tangerang , Selasa 23 Juni 2020

16 Hasil Wawancara dengan Bapak Cama Sebagai Non Anggota Koperasi Syariah BMI Cabang Cikupa Senin 27 April 2020
} 


\section{Daftar Pustaka}

Muhith, Abd. "Aktualisasi Pemahaman Zakat dan Muamlah dalam Memberdayakan Ekonomi Umat". IAIN Jember, vol No 12019.

Saefuddin, Ahmad M. Ekonomi dan Masyarakat dalam Prespektif Islam. Jakarta: CV. Rajawali, 1987.

Qadir, Abdurrachman. Zakat dalam Dimensi Mahdah dan Sosial. Jakarta: Raja Grafindo Persada, 2001.

Wahyu, A. Rio Makkulau dan Wirani Aisiyah Anwar. "Sistem Pengelolaan Zakat Pada Baznas," Al-Azhar: Journal of Islamic Economics, 2, No. 1 2020.

Soemitra, Andri. Bank dan Lembaga Keuangan Syariah: Edisi Kedua. Depok: Kencana, 2017.

Yaqin, Ainol. “Optimalisasi Zakat Produktif Dalam Pengentasan Problem Kemiskinan" Iqtishadia: Jurnal Ekonomi \& Perbankan Syariah 2, No. 2 Fakultas Ekonomi Dan Bisnis Islam IAIN Madura.

Hafidhuddin, Didin. Panduan Praktis Tentang Zakat, Infak, Dan Sedekah. Jakarta: Gema Insani Press, 2009.

Wardhana, Didin. "Optimalisasi Kinerja Satuan Relawan Kebakaran (SATWANKAR) Di Kota Bandung", Jurnal Ilmiah Magister Ilmu Administrasi (JIMIA), Januari 2018.

Nurainah, Damanhur. "Analisis Pengaruh Bantuan Zakat Terhadap Tingkat Kesejahteraan Masyarakat Kabupaten Aceh Utara," Jurnal Visioner \& Strategis 2018.

Novitasari, Erma Dkk. "Analisis Transparansi, Optimalisasi Pengelolaan Zakat Dan Efisiensi Terhadap Lembaga Zakat Infaq Dan Shodaqoh Muhammadiyah (LAZISMU) Kabupaten Ponorogo," ASSET: Jurnal Manajemen Dan Bisnis 1, No. 2 (6 April 2020).

Nasar, Fuad Dkk. Fiqh Zakat Indonesia. Jakarta: Baznas, Cetakan Ke-2, 2015. Hasanuri, Hasanuri, "Pengembangan Zakat Uintuk Perekonomian Masyarakat," Al-Kharaj: Journal Of Islamic Economic And Business 1, No. 2 (8 Februari 2020).

Nur, Husni Ramdani F, "Effectiveness Of The Utilization Of Zakat Infaq Sadaqah Perspective Maqashid Syariah Study On Dompet Peduli Umat Daarut Tauhiid (DPU DT) Yogyakarta". Fakultas Ilmu Agama Islam Universitas Islam Indonesia Yogyakarta, 11 November 2018.

Utamy, Hebby Rahmatul, "Keadilan Ekonomi Dalam Pendistribusian Zakat Oleh Badan Amil Zakat Nasional (BAZNAS)", Jurnal Tamwil, Vol 1, No 2 Juli-Desember 2015.

Rukminto, Isbandi, Kesejahteraan Sosial. Depok : Rajawali Pers, 2017. 
Nurul, Iman, Dkk. “Membangun Kesadaran Managerial Nadzir Wakaf Produktif Ponorogo Di Era Digital" Universitas Muhammadiyah Ponorogo, Agustus 2019.

Efendi, Jonaedi Dan Johnny Ibrahim. Metode Penelitian Hukum: Normatif Dan Empiris. Depok: Prenada Media, 2018.

Mahalli, Kasyful. "Potensi Dan Peranan Zakat". Jurnal Ekonomi Dan Keuangan 1Departemen Pembangunan USU (2013): .

Ummah, Khurul Aimmatul Dkk, "Pola Impementasi Alokasi ZISWAF Dalam Penyediaan Akses Pendidikan Bagi Kaum Dhuafa," JEBI: Jurnal Ekonomi Dan Bisnis Islam, 3, No. 2 , 3 Desember 2018.

Marlina Dkk, "Pemahaman Zakat Di Kalangan Pengusaha Rumah Makan Di Kota Mataram". Jurnal Of Economic Istinbath, 1 Juni 2018.

Nurwati, Nurwati Dan Heni Hendrawati. "Zakat Dan Upaya Mengentaskan Kemiskinan" Cakrawala: Jurnal Studi Islam 14, No. 1. 2 Agustus 2019.

Mukmin, Nur Dan Susilawati Susilawati, "Pengelolaan Dana Zakat: Studi Akuntabilitas Dan Transparansi Organisasi Pengelola Zakat Di Kota Bogor," Jurnal Akunida 6, No. 1. 8 Juni 2020.

Wiradifa, Riyantama Dan Desmadi Saharuddin. "Strategi Pendistribusian Zakat, Infak, Dan Sedekah (ZIS) Di Badan Amil Zakat Nasional (BAZNAS) Kota Tangerang Selatan," Jurnal Al-Tijary 3, No. 1, 28 Januari 2018.

Muin, Rahmawati. Manajemen Zakat. Makassar: Alauddin University Press, 2011.

Paramita, Shanty Tyas. "Implementasi Fungsi Actuating Dalam Pendayagunaan Dana Zakat Infaq, Shodaqoh Dan Wakaf (ZISWAF)", Skripsi Fakultas Dakwah Dan Komunikasi Universitas Islam Negeri Semarang, 10 Juli 2018.

Wardhana, Didin. "Optimalisasi Kinerja Satuan Relawan Kebakaran (SATWANKAR) Di Kota Bandung." Jurnal Ilmiah Magister Ilmu Administrasi (JIMIA), Januari 2018.

Undang-Undang No 11 Tahun 2009 Tentang Kesejahteraan Sosial, Badan Pusat Statistik Indonesia

Undang-Undang RI No 23 Tahun 2011 Tentang Pengelolaan Zakat

Badan Pusat Statistik Indonesia. Profil Kemiskinan di Indonesia Maret 2020 No. 56/07/Th. XXIII, 15 Juli 2020

Hasil Wawancara dengan Bapak Casmita Selaku Manajer ZISWAF Koperasi Syariah BMI Pusat Pada 27 April 2020 .

Hasil Wawancara dengan Bapak Tony Sehabudin Selaku Staff Lapang Koperasi Syariah BMI Cabang Cikupa Tangerang, Jumat 24 April 2020 
Hasil Wawamcara dengan Bapak Mulyadi S.Ip, Selaku Manajer Koperasi Syariah BMI Cabang Cikupa Tangerang , Selasa 21 April 2020

Hasil Wawancara dengan Bapak Subur Selaku Wakil Ketua IV BAZNAS Kota Tangerang Selasa 23 Juni 2020 